\title{
ANALISIS EPIDEMIOLOGIA PENYAKIT DEMEM BERDARAH DENGUE (DBD) DI KABUPATEN LEBAK 2011 - 2013
}

\begin{abstract}
*Ahmad
Abstrak

Penyakit Demam Berdarah Dengue (DBD) merupakan salah satu masalah kesehatan masyarakat di Indonesia, karena jumlah penderitanya semakin meningkat dan wilayah terjangkitnya semakin meluas. Sejak Kasus demam berdarah dengue, pertama kali ditemukan di Jakarta dan Surabaya pada tahun 1968, sampai saat ini penyakit DBD di Indonesia belum sepenuhnya dapat dikendalikan. Jumlah korban dari tahun ke tahun cenderung mengalami peningkatan seiring dengan meluasnya daerah terjangkit yang hampir menjangkau seluruh wilayah Indonesia. Keadaan yang sama juga terjadi di wilayah Propinsi Banten, termasuk di kabupaten Lebak data DBD pada tahun 2013 berjumlah 249 kasus kasus dan 5 kematian. Secara epidemiologis faktor risiko yang menjadi penyebab kejadian dimaksud sampai saat ini belum teranalisis secara baik Penelitian ini bertujuan untuk mengetahui gambaran epidemiologis penyakit demam berdarah dengue di Kabupaten Lebak tahun 2011 - 2013.Desain yang digunakan pada penelitian ini adalah crossectional study. Penelitian ini menggunakan data sekunder tentang kejadian penyakit demam berdarah dengue yang ada di Dinas Kesehatan Kabupaten Lebak selama tahun 2011 - 2013.

Hasil penelitian menunjukkan Kasus penyakit demam berdarah selama tahun 2011 2013 di Kabupaten Lebak sebanyak 648 kasus. Proporsi kejadian penyakit demam berdarah di Kabupaten Lebak tahun 2011 - 2013 relatif sama antara laki - laki dengan perempuan masing - masing $49.1 \%$ dan 50,9 \% , dengan usia terendah berusia 1 tahun dan tertinggi berusia 84 tahun. Penyakit demam berdarah rata - rata menyerang usia produktif setiap tahunnya dengan rentang usia antara 21 sampai 26 tahun. Penderita demam berdarah, sebagian besar $(60 \%)$ tinggal di daerah perkotaan, sementara sebagaian kecil lainnya tinggal di pedesaan. Penyakit ini sebagian besar menyerang penduduk di tiga kecamatan, sementara sebagian kecil lainnya tersebar di 25 kecamatan lainnya di Kabupaten Lebak.Penyakit demam berdarah di beberapa tempat di Kabupaten Lebak sudah termasuk penyakit endemic, karena penyakit ini selalu ditemukan setiap bulannya.Penyakit ini cenderung meningkat pada bulan Desember sampai dengan Pebruari setiap tahunnya. Rata - rata kematian akibat penyakit demam berdarah di Kabupaten Lebak dalam tiga tahun terakhir sebanyak $2 \%$, yang berarti setiap 100 penderita demam berdarah akan terjadi kematian 2 orang.

Perlunya petugas kesehatan memberikan penyuluhan tentang pencegahan dan pengendalian penyakit demam berdarah kepada masyarakat khususnya di wilayah perkotaan Kabupaten Lebak mengingat penyakit ini sebagian besar diderita oleh masyarakat perkotaan Kabupaten Lebak. Selain itu, Keluarga dapat mengenali penyakit demam berdarah lebih dini, sehingga penangan penyakit ini semakin baik dan tingkat kematian akibat penyakit demam berdarah dapat ditekan.
\end{abstract}

Kata Kunci: Penyakit Epidemiologi, Demam Berdarah

*Poltekkes Kemenkes Banten 


\section{Pendahuluan}

Penyakit Demam Berdarah Dengue ( DBD ) adalah penyakit yang disebabkan oleh virus Dengue dan ditularkan melalui gigitan nyamuk Aedes aegypti atau Aedes albopictus. Penyakit Demam Berdarah Dengue (DBD) merupakan salah satu masalah kesehatan masyarakat di Indonesia, karena jumlah penderitanya semakin meningkat dan wilayah terjangkitnya semakin meluas.

Data yang ada menunjukkan bahwa di antara negara-negara ASEAN, Indonesia menduduki urutan kedua tertinggi kasus DBD yaitu sebesar 39.405 kasus, setelah Vietnam yang merupakan negara dengan kasus DBD tertinggi yaitu sebesar 234.920 kasus, diikuti Thailand sebesar 24.826 kasus, Filipina 12.121 kasus, Singapura 1.355 kasus, Malaysia 605 kasus, dan Brunei Darussalam dengan 7 kasus (Sulani F, 2004).

Sebagaimana diketahui bahwa sampai saat ini obat untuk membasmi virus dan vaksin untuk mencegah penyakit Demam Berdarah Dengue belum tersedia.Cara yang tepat guna untuk menanggulangi penyakit ini secara tuntas adalah memberantas vektor/nyamuk penular.

Vektor Demam Berdarah Dengue mempunyai tempat perkembangbiakan yakni di lingkungan tempat tinggal manusia terutama di dalam stan diluar rumah. Nyamuk Aedes aegypti berkembangbiak di tempat penampungan air seperti bak mandi, drum, tempayan dan barang-barang yang memungkinkan air tergenang seperti kaleng bekas, tempurung kelapa, dan lain-lain yang dibuang sembarangan.

Pemberantasan vektor Demam Berdarah Dengue dilaksanakan dengan memberantas sarang nyamuk untuk membasmi jentik nyamuk Aedes aegypti.Mengingat nyamuk Aedes aegypti tersebar luas diseluruh tanah air baik dirumah maupun tempat-tempat umum, maka untuk memberantasnya diperlukan peran serta seluruh masyarakat.

Kasus demam berdarah dengue, pertama kali ditemukan di Jakarta dan Surabaya pada tahun 1968, sampai saat ini penyakit DBD di Indonesia belum sepenuhnya dapat dikendalikan.Jumlah korban dari tahun ke tahun cenderung mengalami peningkatan seiring dengan 
meluasnya daerah terjangkit yang hampir menjangkau seluruh wilayah Indonesia. Keadaan yang sama juga terjadi di wilayah Propinsi Banten, termasuk di kabupaten Lebak data DBD pada tahun 2013 berjumlah 249 kasus kasus dan 5 kematian. Secara epidemiologis faktor risiko yang menjadi penyebab kejadian dimaksud sampai saat ini belum teranalisis secara baik

Penelitian ini bertujuan untuk mengetahui gambaran epidemiologis penyakit demam berdarah dengue (DBD) di Kabupaten Lebak Tahun $2011-2013$.

Hasil penelitian ini dapat memberikan informasi yang berguna bagi dinas kesehatan guna dijadikan bahan dalam mengambil kebijakan yang berkaitaan dengan pengendalian dan pemberantasan penyakit demam berdarah, disamping itu hasil penelitian ini juga dapat memberikan gambaran tentang karakteristik epidemiologis penyakit demam berdarah di kabupaten Lebak

\section{Metodologi Penelitian}

Penelitian ini dilakukan pada Bulan September sampai dengan
November 2014, dengan desain penelitian Cross Sectional. Desain study Cross Sectional ialah suatu penelitian untuk mempelajari dinamika korelasi antara faktor-faktor resiko dengan efek, dengan cara pendekatan, observasi atau pengumpulan data sekaligus pada suatu saat ( point time approach).

Data yang menyangkut variabel bebas ( variabel risiko ) dan variabel terikat ( variabel akibat ), akan dikumpulkan dalam waktu yang sama (Notoatmodjo, 2010 ). Alasan pemilihan desain study cross sectional karena mudah dilakukan, lebih ekonomis, dan hasilnya dapat diperoleh dengan cepat

Instrumen pengumpulan data yang digunakan pada penelitian ini adalah format pengumpulan data yang penulis susun guna menghimpun data sekunder yang ada di dinas kesehatan Kabupaten Lebak yang berkaitan dengan kejadian demam berdarah

Populasi penelitian ini adalah seluruh penderita demam berdarah yang tercatat pada dinas kesehatan Kabupaten Lebak tahun 2011 - 2013 yang berjumlah 648 orang. Pada penelitian ini penulis mengambil 
seluruh data kejadian demam berdarah yang tercatat pada dinas kabupaten Lebak tahun 2011 - 2013.

Pengumpulan data pada penelitian ini dilakukan dengan mengisi format pengumpulan data yang telah disusun oleh peneliti. Data yang digunakan adalah data sekunder berupa data kejadian penyakit demam berdarah dengue di Kabupaten Lebak yang tercatat di dinas kesehatan Kabupaten Lebak tahun 2011 - 2013.

Pengolahan data merupakan proses yang sangat penting dalam penelitian. Setelah semua data terkumpul, selanjutnya data akan diolah secara manual yang akan disajikan dalam bentuk tabel dan grafik. Proses pengelolaan data terdiri dari Editing, yaitu data yang telah dikumpulkan diperiksa kebenarannya dan dikoreksi kesalahannya dalam pengisian data. Dalam tahap ini data yang dikumpulkan dilakukan pengecekan atas isi form pengumpulan data, sehingga menghasilkan data yang akurat untuk pengolahan data selanjutnya.

Coding, yakni mengubah data berbentuk kalimat atau huruf menjadi data angka atau bilangan. Misalnya tingkat jenis kelamin 1 untuk laki-laki,
2 untuk perempuan. Coding mempermudah pada saat analisa data dan entry data.

Selanjutnya Entery atau processing yaitu setelah semua isian form pengumpulan data terisi penuh dan benar pada semua sampel dan juga sudah melewati pengkodingan, maka langkah selanjutnya adalah memproses data agar dapat dianalisis. Pengolahan data dilakukan dengan cara memasukan data kuesioner ke paket program komputer.

Tabulating yaitu memasukkan data sesuai dengan kelompok data kemudian menyajikan dengan menggunakan tabel atau grafik.

Setelah data dikumpulkan dan diolah, langkah selanjutnya yaitu melakukan analisis data. Secara konsep analisa data dibagi menjadi tiga mcam yaitu analisa univariat, bivariat dan multivariat. Dalam penelitian ini penulis menggunakan data sekunder, sehingga penulis mengalami keterbatasan data yang dikumpulkan, oleh karena itu analis data yang digunakan hanya analisis univariat bertujuan untuk menjelaskan atau mendeskripsikan karakteristik setiap

Jurnal Medikes, Volume 2, edisi 1, April 2015 
variabel penelitian baik variabel dependent maupun variabel independent.

\section{Hasil Penelitian}

\section{Prevalensi Kejadian Demam Berdarah Dengue.}

Kejadian penyakit demam berdarah di Kabupaten Lebak periode tahun 2011 - 2013, sebanyak 648 kasus, yang terdiri 323 kasus laki-laki dan 325 perempuan

\section{Jenis kelamin}

Kejadian penyakit demam berdarah di Kabupaten Lebak berdasarkan jenis kelamin dapat digambarkan sebagai berikut :

Tabel 1

Distribusi penderita demam berdarah berdasarkan jenis kelamin

Di Kabupaten Lebak tahun 2011 - 2013

\begin{tabular}{ccccccc}
\hline Th & \multicolumn{3}{c}{ Jenis kelamin } & \multicolumn{2}{c}{ Jumlah } \\
\cline { 2 - 7 } & $\mathrm{L}$ & $\%$ & $\mathrm{P}$ & $\%$ & & $\%$ \\
\hline 2011 & 83 & 48 & 90 & 52 & 173 & 100 \\
\hline 2012 & 110 & 49 & 116 & 51 & 226 & 100 \\
\hline 2013 & 130 & 53 & 119 & 47 & 249 & 100 \\
\hline Jml & 323 & 49,9 & 325 & 50,1 & 648 & 100
\end{tabular}

Pada table 1 menunjukan bahwa kejadian penyakit demam berdarah di Kabupaten lebak cenderung mengalami peningkatan setiap tahunnya, dengan proporsi kejadian relatif sama antara laki - laki dengan perempuan masing masing $49.1 \%$ dan 50,9\%.

\section{Umur}

Umur penderita penyakit demam berdarah di Kabupaten Lebak tahun 2011 - 2013, dapat digambarkan sebagai berikut :

Tabel 2.

Distribusi penderita demam berdarah berdasarkan umur Di Kabupaten Lebak tahun 2011 - 2013

\begin{tabular}{ccccc}
\hline Th & Min & Maks & Mean & SD \\
& & & & \\
\hline 2011 & 1 th & 84 th & 26,1 th & 15,68 \\
\hline 2012 & 1 th & 74 th & 22.4 th & 14,01 \\
\hline 2013 & 1 th & 80 th & 21,2 th & 14,99 \\
\hline
\end{tabular}

Pada table 2 menunjukkan bahwa umur penderita demam berdarah di Kabupaten Lebak tahun 2011 - 2013 terendah berusia 1 tahun dan tertinggi berusia 84 tahun. Penyakit demam berdarah rata - rata menyerang usia produktif setiap tahunnya dengan rentang usia antara 21 sampai 26 tahun.

\section{Tempat}

Pengelompokan tempat tinggal dibagi dua kategori yaitu daerah perkotaan dan daerah pedesaan 
berdasarkan jarak ke ibu kota kabupaten Lebak. Kabupaten Lebak memiliki 28 kecamatan. Berdasarkan definisi operasional tentang tempat, maka perkotaan meliputi tiga kecamatan yang ada di Kabupaten Lebak yaitu kecamatan

Rangkasbitung, kecamatan Cibadak dan Kecamatan Kalanganyar, sementara 25 kecamatan lainnya dikategorikan daerah pedesaan. Berdasarkan tempat tingal penderita demam berdarah di Kabupaten Lebak tahun 2011 - 2013, dapat digambarkan sebagai berikut :

Tabel 3.

Distribusi penderita demam berdarah berdasarkan tempat tinggal penderita

Di Kabupaten Lebak tahun 2011 - 2013

\begin{tabular}{ccccccc}
\hline Th & \multicolumn{3}{c}{ Tempat tinggal } & \multicolumn{2}{c}{ Jml } \\
\cline { 2 - 7 } & Kota & $\%$ & Desa & $\%$ & F & $\%$ \\
\hline 2011 & 116 & 67 & 57 & 33 & 173 & 100 \\
& & & & & & \\
\hline 2012 & 118 & 52 & 108 & 48 & 226 & 100 \\
& & & & & & \\
\hline 2013 & 160 & 64 & 89 & 36 & 249 & 100 \\
\hline Jml & 394 & 60 & 354 & 40 & 648 & 100 \\
\hline
\end{tabular}

Pada table 3 menunjukan bahwa penderita demam berdarah, sebagian besar $(60 \%)$ tinggal di daerah perkotaan, sementara sebagaian kecil lainnya tinggal di pedesaan. Tabel ini juga menunjukan bahwa kejadian demam berdarah sebagian besar menyerang penduduk di tiga kecamatan, sementara sebagian kecil lainnya tersebar di 25 kecamatan lainnya di Kabupaten Lebak.

Berdasarkan lokasi kecamatan yang ada di Kabupaten Lebak, beberapa kecamatan dalam tiga tahun terakhir, menunjukkan zero kasus untuk penyakit demam berdarah. Kecamatan tersebut dapat dijelaskan sebagai berikut :

Tabel 4.

Distribusi kecamatan yang tidak terdapat penderita demam berdarah

\begin{tabular}{lrl}
\multicolumn{3}{c}{ Di Kabupaten Lebak tahun $2011-2013$} \\
\hline Th Jml Kecamatan
\end{tabular}

\begin{tabular}{lll}
\hline 2011 & 11 & $\begin{array}{l}\text { Curugbitung, Lebak gedong, } \\
\text { Sobang, } \\
\text { banjarsari, Binuangen, Cijaku, } \\
\text { Cigemblong, Cihara, Cilograng, } \\
\text { Cibeber }\end{array}$ \\
\hline 2012 & 4 & $\begin{array}{l}\text { Cijaku, } \\
\text { Curugbitung, Cihara }\end{array}$ \\
\hline 2013 & 6 & $\begin{array}{l}\text { Binuangen, Cijaku, Cigemblong, } \\
\text { Cihara, Cilograng, Cibeber. }\end{array}$ \\
\hline
\end{tabular}

Table 4 menunjukan bahwa wilayah kecamatan di Kabupaten Lebak yang penduduknya terserang penyakit demam berdarah, semakin banyak, sehingga hampir seluruh kecamatan di Kabupaten Lebak sudah 
terjangkit demam berdarah, kecuali

\section{Waktu}

Berdasarkan waktu kejadian penyakit demam berdarah, di Kabupaten Lebak menunjukan bahwa penyakit demam berdarah sudah termasuk penyakit endemic di beberapa tempat di kabupaten Lebak, karena penyakit ini selalu ditemukan setiap bulannya.
Cijaku, Cigemlong dan Cihara.

Penyakit ini cenderung meningkat pada bulan Desember sampai dengan Pebruari setiap tahunnya. Lebih jelasnya tentang gambaran waktu kejadian penyakit demam berdarah dapat digambarkan sebagai berikut :
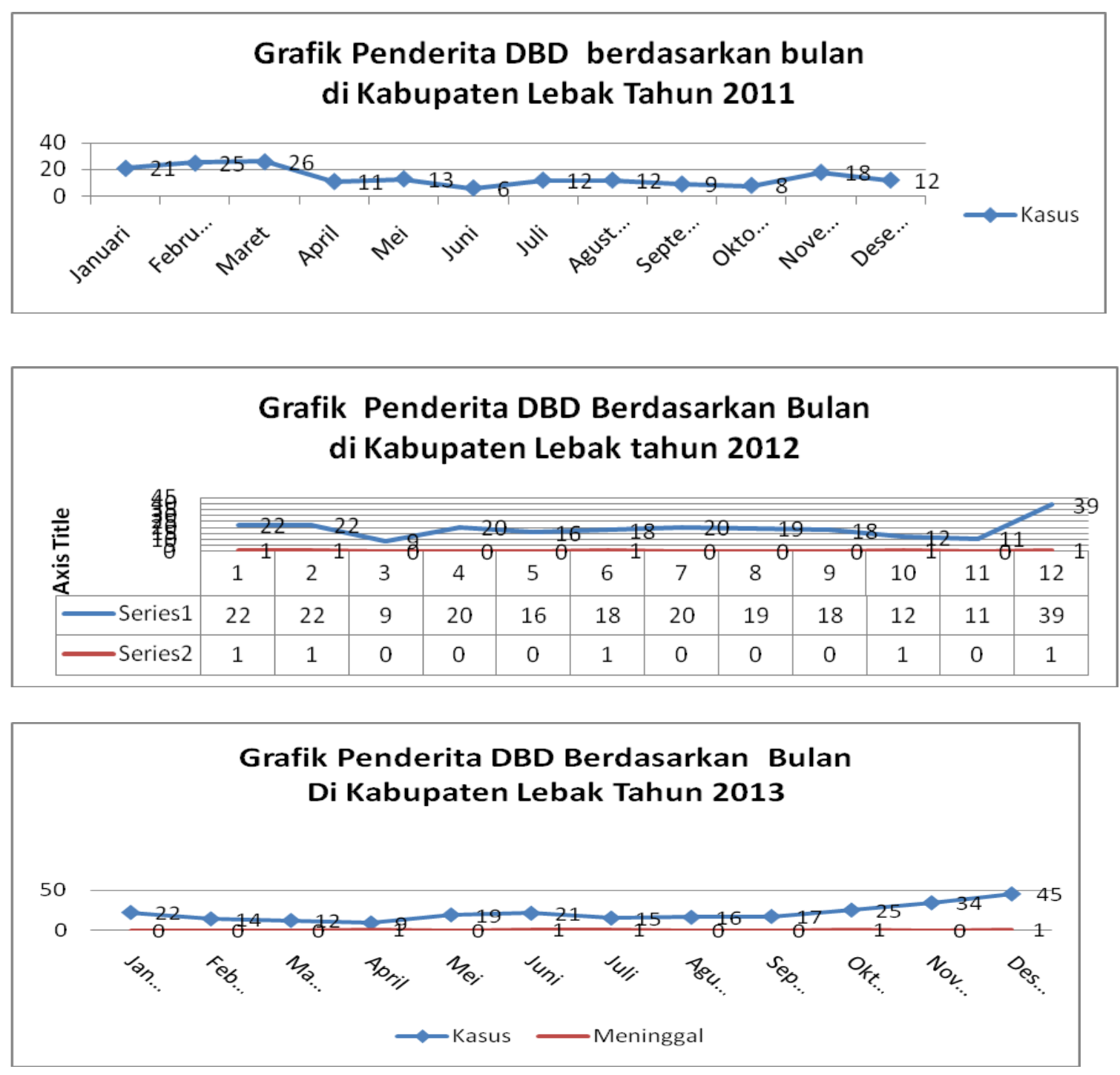


\section{Keganasan Penyakit DBD}

Kematian akibat penyakit demam berdarah dalam kurun waktu 2011 - 2013, yang tercatat pada laporan dinas kesehatan kabupaten Lebak sebanyak 13 orang. Lebih jelasnya tentang kematian akibat penyakit demam berdarah, dapat digambarkan sebagai berikut :

Tabel 5.

Distribusi kematian penderita demam berdarah Di Kabupaten Lebak tahun 2011 - 2013 Th Kasus Meninggal CFR

\begin{tabular}{cccc}
\hline 2011 & 173 & 3 & $1.73 \%$ \\
\hline 2012 & 226 & 5 & $2,21 \%$ \\
\hline 2013 & 249 & 5 & $2,00 \%$ \\
\hline Jml & 648 & 13 & $2,00 \%$
\end{tabular}

Pada table 5 menunjukkan bahwa rata-rata kematian akibat penyakit demam berdarah di Kabupaten Lebak dalam tiga tahun terakhir sebanyak $2 \%$, yang berarti setiap 100 penderita demam berdarah akan terjadi kematian 2 orang.

\section{Pembahasan}

\section{Prevalensi Penyakit Demam Berdarah}

Selama kurun waktu 2011 2013 kasus demam berdarah di Kabupaten Lebak sebanyak 648 kasus, sementara jumlah penduduknya sebanyak 1.260 .773 jiwa pada tahun 2013.Data tahun 2013 menunjukan bahwa penyakit demam berdarah di Kabupaten Lebak sebanyak 249 kasus. Hal ini menggambarkan bahwa prevalensi demam berdarah pada tahun 2013 sebesar 19,7 per 100.000 penduduk. Angka ini masih dibawah target angka nasional tentang pengendalian penyakit demam berdarah yang menetapkan maksimal prevalens demam berdarah sebanyak 51 / 100.000 penduduk. Walaupun angka kejadian penyakit demam berdarah relative rendah dibanding angka nasional, namun bila dilihat dari kecendrungan angka kejadiannya terus mengalami peningkatan setiap tahunnya. Hal lainnya penyakit demam berdarah, sering kali menimbulkan kepanikan bagi keluarga penderita karena gejala 
penyakit ini sering menunjukan demam tinggi dan kekhawatiran akan terus menurunnya kadar trombosit penderitanya.

Memperhatikan kondisi ini, maka perlu kirannya pemerintah maupun masyarakat memperhatikan upaya pengendalian dan pemberantasan penyakit demam berdarah.

Dalam upaya penanggulangan Demam Berdarah Dengue, pemerintah mempunyai 4 (empat)pilar strategi.Pertama, memperkuat pengamatan kasus/penderita dan pengamatan vectordidukung dengan laboratorium yang memadai; Kedua, memperkuat penatalaksanaan penderitadi rumah sakit, puskesmas dan klinik; Ketiga, meningkatkan upaya pengendalian vektor secaraterpadu; Keempat, memperkuat kemitraan dengan berbagai pihak dalam pencegahan danpenanggulangan penyakit DBD.Dalam rangka mendukung pelaksanaan strategi pemerintahtersebut maka diperlukan upaya pembangunan kualitas SDM kesehatan yang memadai dalampengendalian

Demam Berdarah Dengue.

\section{Jenis Kelamin}

Hasil penelitian menunjukan bahwa kejadian penyakit demam berdarah di Kabupaten lebak cenderung mengalami peningkatan setiap tahunnya, dengan proporsi kejadian relatif sama antara laki laki dengan perempuan masing masing $49.1 \%$ dan $50,9 \%$. Gambaran ini menunjukan bahwa penyakit demam berdarah tidak menunjukan risiko yang dominan pada jenis kelamin tertentu, oleh karenanya laki -laki dan perempuan memiliki risiko yang sama untuk menderita penyakit ini. Proporsi kejadian demam berdarah di Kabupaten Lebak ini, relative sama dengan gambaran proporsi kejadian demam berdarah pada tingkat nasional, dimana kejadian penyakit berdarah pada perempuan sedikit lebih tinggi dibanding laki - laki yaitu perempuan 50,33\% dan lakilaki $49,67 \%$. 


\section{Umur}

Penyakit demam berdarah dengue, merupakan penyakit yang menyerang setiap kelompok umur. Hasil penelitian menunjukan bahwa umur penderita demam berdarah dengue, yang terjadi di Kabupaten Lebak pada periode 2011 - 2013 berkisar antara 1 tahun hingga 84 tahun, dengan rata - rata umur penderita penyakit demam berdarah berusia 21 - 26 tahun.

Gambaran itu menunjukan bahwa sebagian besar penderita demam berdarah berusia produktif. Dengan kata lain bahwa kelompok usia produktif memiliki risiko lebih tinggi dibanding kelompok usia lainnya.

Hal ini bisa terjadi karena, kelompok usia produktif relative besar mobilitasnya, sehingga kemuningkinan untuk berinteraksi dengan daerah lain ataupun berinteraksi dengan nyamuk aedes aegypti yang merupakan vector penyakit demam berdarah semakin tinggi.

Beberapa hasil penelitian lain menunjukan bahwa pada anak-anak biasanya menunjukan gejala yang lebih ringan dibanding usia yang lebih tinggi (dewasa).

Penderita yang sembuh dari infeksi dengan satu jenis serotype akan memberikan imunitas seumur hidup, tetapi tidak memberikan perlindungan terhadap infeksi serotype lain dan dapat terjadi infeksi lagi oleh serotype lainnya.

\section{Tempat Tinggal}

Hasil penelitian menunjukan bahwa penderita demam berdarah, sebagian besar $(60 \%)$ tinggal di daerah perkotaan, sementara sebagian kecil lainnya tinggal di pedesaan. Hasil penelitian juga menunjukan bahwa kejadian demam berdarah sebagian besar menyerang penduduk di tiga kecamatan, yang termasuk daerah perkotaan, sementara sebagian kecil lainnya tersebar di 25 kecamatan lainnya di Kabupaten Lebak.

Hasil ini menggambarkan bahwa penyakit demam berdarah, lebih dominan terjadi di perkotaan.

Daerah perkotaan umumnya merupakan daerah yang memiliki kepadatan penduduk yang tinggi dan mobilitas penduduk yang tinggi 
pula, sementara penduduk di daerah pedesaan sangat rendah kejadian kasus demam berdarahnya. Pada kelompok masyarakat pedesaan umunya tingkat mobiltasnya rendah, dengan penduduk yang tidak terlalu padat.

Hasil analisis juga menggambarkan sampai dengan 2013, masih ada beberapa kabupaten di Kabupaten lebak yang penduduknya belum pernah menderita demam berdarah dengue. Daerah yang belum memiliki kasus pasien demam berdarah dalam tiga tahun terkahir antara lain Kecamatan Cijaku, Cigemblong, Cihara, dan Cibeber. Daerah-daerah ini pada umumnya merupakan daerah pegunungan, sehingga nyamuk anopheles sebagai vector peyakit demam berdarah tidak dapat berkembang.

Dari gambaran yang ada, menunjukan bahwa daerah yang terkena penyakit demam berdarah setiap tahun cenderung mengalami perluasan, sehingga hampir seluruh wilayah kecamatan di Kabupaten Lebak sudah ada yang menderita penyakit demam berdarah.

\section{Waktu}

Hasil penelitian menunjukan bahwa berdasarkan waktu kejadian penyakit demam berdarah, di Kabupaten Lebak menunjukan, penyakit demam berdarah sudah termasuk penyakit endemic di beberapa tempat di kabupaten Lebak, karena penyakit ini selalu ditemukan setiap bulannya. Penyakit ini cenderung meningkat pada bulan Desember sampai dengan Pebruari setiap tahunnya.

Gambaran ini menjelaskan bahwa, setiap saat masyarakat harus selalu waspada terhadap kemungkinan terinfeksi oleh virus dengue. Risiko penyakit ini semakin besar terutama saat terjadinya perubahan cuaca dari musim hujan ke musim kering atau sebaliknya.

Penentuan musim hujan ke musin kering, saat ini relative sulit dipastikan mengingat adanya perubahan iklim (climate change). Untuk menghindari terjadinya penyakit demam berdarah, antara lain perlunya melakukan pengelolaan lingkungan yang baik, mengelola dan mengolah sampah dengan baik, 
hingga menghindari gigitan nyamuk aedes aegypti.

\section{Case Fatality Rate}

Penyakit demam berdarah, memiliki risiko tinggi untuk menimbulkan kematian bagi penderitanya, apabila penanganan penyakit ini kurang baik.

Hasil penelitian menunjukan bahwa angka kematian akibat penyakit demam berdarah dalam tiga tahun terakhir rata - rata $2.00 \%$. Angka ini relative tinggi dibandingkan angka case fatality rate tingkat nasional yang hanya sebesar $0,87 \%$.

Masih tingginya angka case fatality rate tersebut, kemungkinan penanganan kasus demam berdarah di tingkat rumah tangga maupun rumah sakit masih kurang baik.

Sering kali keluarga kurang memperhatikan kemungkinan terjangkitnya penyakit demam berdarah, apabila keluarganya menderita sakit dengan gejala / keluhan panas, sehingga penderita cenderung dirawat ke pelayanan kesehatan dengan kadar trombosit yang sudah turun. Kondisi ini tentu memperburuk keadaan penderita demam berdarah.

\section{Simpulan}

Dari hasil penelitian yang telah diuraikan, dapat penulis simpulkan sebagai berikut :

1. Kasus penyakit demam berdarah selama tahun 2011 - 2013 di Kabupaten Lebak sebanyak 648 kasus.

2. Proporsi kejadian penyakit demam berdarah di Kabupaten Lebak tahun 2011 - 2013 relatif sama antara laki - laki dengan perempuan masing - masing 49.1 $\%$ dan $50,9 \%$.

3. Umur penderita demam berdarah di Kabupaten Lebak thn 20112013 terendah berusia 1 tahun dan tertinggi berusia 84 tahun. Penyakit demam berdarah rata rata menyerang usia produktif setiap tahunnya dengan rentang usia antara 21 sampai 26 tahun.

4. Penderita demam berdarah, sebagian besar $(60 \%)$ tinggal di daerah perkotaan, sementara sebagaian kecil lainnya tinggal di pedesaan. Penyakit demam berdarah sebagian besar 
menyerang penduduk di tiga kecamatan, sementara sebagian kecil lainnya tersebar di 25 kecamatan lainnya di Kabupaten Lebak.

5. Penyakit demam berdarah sudah termasuk penyakit endemic di beberapa tempat di kabupaten Lebak, karena penyakit ini selalu ditemukan setiap bulannya. Penyakit ini cenderung meningkat pada bulan Desember sampai dengan Pebruari setiap tahunnya.

6. Rata - rata kematian akibat penyakit demam berdarah di Kabupaten Lebak dalam tiga tahun terakhir sebanyak $2 \%$, yang berarti setiap 100 penderita demam berdarah akan terjadi kematian 2 orang.

Dari simpulan yang penulis temukan, maka penulis menyarankan bahwa petugas kesehatan perlu memberikan penyuluhan tentang pencegahan dan pengendalian penyakit demam berdarah kepada masyarakat khususnya di wilayah perkotaan Kabupaten Lebak mengingat penyakit ini sebagian besar diderita oleh masyarakat perkotaanKabupaten Lebak.

Perlunya keluarga memahami karakteristik penyakit demam berdarah, agar keluarga dapat mengenali penyakit demam berdarah lebih dini, sehingga penangan penyakit ini semakin baik dan tingkat kematian akibat penyakit demam berdarah

\section{Daftar Pustaka}

Bhisma Murti, Prinsip dan Metode Riset Epidemiologi, Gajahmada University Press, Jogjakarta, 2005

Departemen Kesehatan RI - WHO, Pencegahan dan Penanggulangan Penyakit Demam Berdarah Dengue, Jakarta 2003

Departemen Kesehatan RI, Modul Surveilans, Jakarta 2004

Departemen kesehatan RI, Pedoman Umum Kegiatan Surveilans, Jakarta 2000

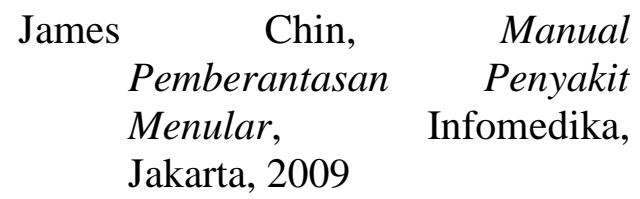

Kementerian Kesehatan RI, Modul Pelatihan Penanggulangan Penyakit Demam Berdarah Dengue, Jakarta, 2011 